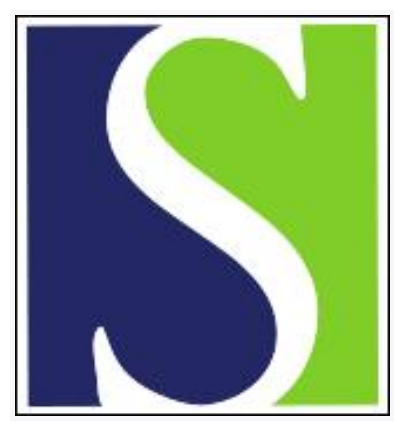

Scand J Work Environ Health 1986;12(6):523-537

https://doi.org/10.5271/sjweh.2104

Issue date: Dec 1986

Airborne cadmium and carcinogenesis of the respiratory tract. by Oberdorster $\mathrm{G}$

This article in PubMed: www.ncbi.nlm.nih.gov/pubmed/3547632

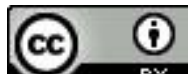




\title{
Airborne cadmium and carcinogenesis of the respiratory tract
}

\author{
by Günter Oberdörster, DrMedVet ${ }^{1}$
}

\begin{abstract}
OBERDÖRSTER G. Airborne cadmium and carcinogenesis of the respiratory tract. Scand $J$ Work Environ Health 12 (1986) 523-537. Exposure to airborne cadmium occurs mainly at the workplace. Significant exposure also occurs through smoking. Results of a recent epidemiologic study suggest that occupational inhalation of cadmium is connected with an increased lung cancer risk. This finding corroborates the high lung cancer incidence found among rats after chronic low-level exposure to cadmium chloride aerosols. Differences in the tumor sites, exposure conditions, and the pulmonary metabolism of cadmium between rodents and man make it difficult to extrapolate quantitatively from rats to humans. In contrast to the workplace, concentrations of cadmium in ambient air are very low, and the risk of lung cancer is probably very low, even for people living close to cadmium-emitting industries. The chemical form of inhaled cadmium appears to be important. While cadmium oxide and cadmium chloride seem to be equally toxic, cadmium sulfide exhibits a lower acute pulmonary toxicity. However, whether this is also true for carcinogenic effects is not known. Additional long-term inhalation studies with animals and further evaluation of epidemiologic studies are necessary to answer questions about the carcinogenic potency of cadmium compounds of different chemical form. As long as such results are not available, it is prudent to regard all cadmium compounds as having a carcinogenic potential.
\end{abstract}

Key terms: ambient air, animal studies, cadmium aerosols, epidemiology, lung tumor, occupational exposure.

The first indication of a cadmium compound having a carcinogenic effect appeared in 1961 after subcutaneous injection to rats (28). This finding was followed by a series of experiments confirming that cadmium, when given parenterally by injection to rats and mice, can induce tumors $(26,29,42)$. Relevant human exposure to cadmium, however, occurs mainly through the oral intake of food and drinking water and, in certain situations, through the inhalation of cadmiumcontaminated air. No carcinogenic effect has been found after the oral administration of cadmium (52). However, Takenaka et al (99) reported recently that inhaled cadmium chloride aerosols can induce carcinomas in the lungs of rats. Very recently Thun et al (101) reported that mortality from respiratory cancer in humans occupationally exposed to cadmium was significantly increased. These findings have led to a renewed interest in the carcinogenic potential of inhaled cadmium compounds for humans, and the following is a brief review of current knowledge on this subject, as well as a discussion of experimental evidence, some mechanistic aspects, and future research needs.

\section{Human exposures}

Although cadmium is found throughout the lithosphere, mainly in sulfide deposits, an increased disper-

\footnotetext{
1 Department of Biophysics, Division of Toxicology, University of Rochester, Rochester, New York, United States.

Reprint requests to: Dr G Oberdörster, Department of Biophysics, Division of Toxicology, University of Rochester, Rochester, NY 14642, USA.
}

sion into the biosphere occurred only towards the end of the last century with the commercial production of cadmium from zinc ores. Today, cadmium contaminates soil, water, and air through several pathways, eg, mining, refining and smelting operations; burning of fossil fuel; municipal waste incineration; use of sludge; phosphate fertilizers; and several industrial manufacturing processes (14). Accordingly, contamination of food and drinking water, and even air, can be rather high, and concerns about the bioaccumulation and persistence of cadmium and its possible longterm effects has prompted the National Swedish Environment Protection Board (65) to impose a ban on the import and use of certain cadmium-containing compounds. This action is in accord with the recommendation of the joint FAO/WHO Expert Committee on Food Additives "that every effort should be made to limit, and even to reduce, the existing pollution of the environment with cadmium [p 56]" (22).

By the mid-1970s, worldwide cadmium consumption was about $18000 \mathrm{t} /$ year (12). Countries with major cadmium production include the Soviet Union, Japan, the United States (US), the Federal Republic of Germany, and Belgium. About $4000 \mathrm{t}$ of cadmium are used yearly in the US, roughly $50 \%$ for the plating of metals and another $50 \%$ for pigments, batteries, stabilizers in plastics, metallurgy, nuclear reactor rods, the semiconductor industry, and catalysts (63). According to an estimate by the National Institute of Occupational Safety and Health (NIOSH), approximately 1.5 million workers are potentially exposed to cadmium in these industries in the US, and of these 0.1 million are exposed to specific cadmium compounds (63). The cadmium-containing particles to which these workers 
are exposed can be quite different chemically and physically, depending on the process by which they are generated. For example, in zinc-, lead-, and copper-ore smelting operations, cadmium oxide fume will be the predominant form of cadmium exposure, whereas, during cadmium-coating processes of metals, mists and dusts of cadmium cyanate, cadmium chloride, and cadmium oxide can be possible sources of exposure. Exposure to cadmium oxide can be in the form of fumes - when generated by combustion or heating processes - or in the form of dust - when generated by mechanical operations. During the calcination of cadmium pigments, exposure to cadmium sulfide particles may occur. Organic derivatives of cadmium can be sources of exposure when cadmium is used as a stabilizer for plastics and as a catalyst (45).

Concentrations of cadmium in the air of workplaces in industries using cadmium were historically very high, in the milligram per cubic meter range, but have decreased since the 1960 s and are now generally below the current federal occupational limit of $200 \mu \mathrm{g} / \mathrm{m}^{3}$ (US) for cadmium dust $(2,82,92)$. A similar decline in occupational cadmium exposure below the exposure limit has also been reported for other countries with an occupational exposure limit of $50 \mu \mathrm{g} / \mathrm{m}^{3}(17,95)$. Reported values for the exposure of the general population are considerably lower. In Europe and the US, the measured annual average cadmium concentrations in rural areas ranged from 0.2 to $6 \mathrm{ng} / \mathrm{m}^{3}$, in urban areas concentrations from 2 to $23 \mathrm{ng} / \mathrm{m}^{3}$ with shortterm values up to $300 \mathrm{ng} / \mathrm{m}^{3}$ were found, and cadmium air concentrations in industrial areas ranged from 10 to $75 \mathrm{ng} / \mathrm{m}^{3}$ with short-term values of about $700 \mathrm{ng} / \mathrm{m}^{3}$ (12). A $24-\mathrm{h}$ maximum value of $5.4 \mu \mathrm{g} / \mathrm{m}^{3}$ $100 \mathrm{~m}$ from a cadmium-emitting factory was also reported (23). Most of the cadmium-containing particles were below $2 \mu \mathrm{m}$ in diameter.

Considering these relatively low concentrations in the ambient air, the intake of cadmium via the respiratory tract is very low for most of the general population. For a person living in an industrial area where the average cadmium concentration in the air may be $50 \mathrm{ng} / \mathrm{m}^{3}$, the amount deposited daily in the deep lung would be $0.25 \mu \mathrm{g}$ (on the assumption of a ventilation rate of $20 \mathrm{~m}^{3} / \mathrm{d}$ and a deposition fraction of 25 $\%$ ). This is a small amount compared to the average daily intake via food and water, which is estimated to be $10-25 \mu \mathrm{g}$ in most countries (personal communication from G Nordberg, 1986). However, absorption has to be taken into account when the uptake of cadmium resulting from inhalation and ingestion is compared. Absorption of cadmium is quite different for the gastrointestinal tract and for the respiratory tract. Only about $6 \%$ of ingested cadmium is absorbed (23), whereas absorption from the alveolar region of the lung can be more than $90 \%$, according to animal studies (48) and estimates from autopsy cases (12). In the preceding example the actual daily absorption of cadmium into the body during chronic inhalation could thus be almost identical to the dose deposited daily in the lung; this possibility underlines the importance of the pulmonary uptake route for cadmium. Both pulmonary and renal effects are well documented in workers occupationally exposed to airborne cadmium (3, $8)$. In contrast, the lung does not represent a target organ for ingested cadmium, since cadmium absorbed from the gastrointestinal tract does not accumulate in the lung and does not show biological effects there, such as the induction of metallothionein (72). Only when very high oral doses of cadmium (as sulfate) were given to mice for several weeks, which led to severe kidney and liver damage, could an interstitial proliferation in the lung be seen (7).

The cadmium content of cigarettes is a significant source of the lung and body cadmium burden in smokers, as pointed out by Lewis et al (50). Between about 1 and $2 \mu \mathrm{g}$ of cadmium per cigarette has been measured (62), and it has been estimated that a one-packper-day smoker will take in about $2-4 \mu \mathrm{g}$ of cadmium (77).

Cadmium inhaled at high concentrations induces pulmonary edema and pneumonitis and affects type I epithelial cells, alveolar macrophages, and interstitial cells $(4,15,23,25,41,74)$. Chronic effects of inhaled cadmium on the lung include fibrosis, emphysema, and bronchitis $(23,36,93)$.

Relatively high concentrations of inhaled cadmium were needed to induce these effects, whereas lung tumors were found after chronic low-level exposure of rats to cadmium chloride aerosols (99). In humans the occurrence of chronic effects from low-level long-term exposure, in particular with regard to lung tumors, is not generally accepted. This position is partly due to the many difficulties inherent in the interpretation of results from epidemiologic studies. It is also questionable whether the different chemical forms of cadmium to which humans are exposed occupationally should be considered equally toxic. Epidemiologic studies investigating an association between lung cancer and cadmium exposure are summarized in the following section.

\section{Respiratory cancer incidence in humans}

Within the past 20 years several epidemiologic studies have been published reporting cancer incidences resulting from cadmium exposure $(3,17,37,38,44,46,49$, $82,95,101,106)$. The studies are summarized in table 1.

In several of these studies, a positive correlation between cadmium exposure and increased risk of prostatic cancer has been reported. Piscator (78) questioned this correlation by pointing out the importance of personal life-style factors for the epidemiology of cancer of the prostate. This aspect of chronic cadmium exposure will not be considered in the present review.

With regard to lung cancer, the following findings have been reported. Lemen et al (49) conducted a study 
on 292 workers who had been employed from 1940 through 1969 in a cadmium smelter for a minimum of two years. Average concentrations of cadmium in the air were derived from measurements in 1947 and 1973. In 1947 they were found to range from 0.04 to $6.59 \mathrm{mg} / \mathrm{m}^{3}$ for cadmium fumes and up to 17.23 $\mathrm{mg} / \mathrm{m}^{3}$ for cadmium dust, but in most cases they were below $1.5 \mathrm{mg} / \mathrm{m}^{3}$. In 1973, air concentrations were mostly below $1 \mathrm{mg} / \mathrm{m}^{3}$ but were sometimes measured to be as high as $24 \mathrm{mg} / \mathrm{m}^{3}$ for an 8 -h time-weighted average. Causes and numbers of deaths, as reported on death certificates, were compared to cause-specific mortality rates for the white male US population. Total malignant neoplasms were significantly increased. Twelve malignant respiratory cancer cases were found versus 5.1 expected $(p<0.05)$. Eight of the tumors had been diagnosed as either squamous-cell carcinoma, anaplastic carcinoma, undifferentiated small-cell carcinoma or oat-cell carcinoma. The authors could not correct for confounding factors like smoking and exposure to other heavy metals, in particular arsenic. Arsenic had been produced in the plant until 1926, and low concentrations $\left(0.3-1.4 \mu \mathrm{g} / \mathrm{m}^{2}\right)$ were still measured in the 1973 survey. Inhaled arsenic has been found to be associated with an increased incidence of lung tumors in humans (75). Thus the finding of an association between lung cancer and cadmium exposure in this study may have been confounded.

The second epidemiologic study on lung cancer and cadmium exposure was published by Holden (37). The mortality of 347 workers in the cadmium-copper alloy department of a cadmium factory was compared to that of 537 brass and iron workers of a foundry. In addition, a cohort of 624 men working for a minimum of 12 months in the cadmium factory outside the cadmium-copper alloy department were included as "vicinity workers." Although a significantly increased mortality from pulmonary diseases was found among the cadmium-copper alloy workers, it was not due to lung cancer. On the other hand, vicinity workers who had been exposed to much lower concentrations of cadmium than the factory workers showed a significant excess of cancer of the lung with 36 observed versus 27 expected cases $(p<0.05)$. However, the author reported that the vicinity workers may have been exposed to other metals, including arsenic, although no measurements of air concentrations had been made. Because of the lack of such measurements and the absence of data on the smoking history of these workers, no definite conclusions regarding the pulmonary car-

Table 1. Epidemiology of cadmium carcinogenesis in relation to the respiratory tract.

\begin{tabular}{|c|c|c|c|}
\hline Author & Study group & Exposure ${ }^{a}$ & Findings \\
\hline Potts (82) & $\begin{array}{l}74 \text { workers in an alkaline } \\
\text { battery factory }\end{array}$ & CdO dust & $\begin{array}{l}\text { One cancer of bronchus (no group for } \\
\text { comparison) }\end{array}$ \\
\hline $\begin{array}{l}\text { Kipling \& } \\
\text { Waterhouse (44) }\end{array}$ & 246 workers & CdO dust & No excess lung cancers \\
\hline Humperdinck (38) & $\begin{array}{l}536 \text { workers in an alkaline } \\
\text { battery plant }\end{array}$ & $\mathrm{Cd}(\mathrm{OH})_{2}, \mathrm{Ni}(\mathrm{OH})_{2}$ & No excess cancer of any organ \\
\hline Lemen et al (49) & $\begin{array}{l}292 \text { cadmium smelter } \\
\text { workers }\end{array}$ & $\mathrm{CdO}$ (some As) & $\begin{array}{l}\text { Increased mortality due to lung cancer } \\
\text { (No correction for arsenic or smoking) }\end{array}$ \\
\hline Kjellström et al (46) & $\begin{array}{l}269 \text { workers in a } \\
\text { cadmium-nickel factory } \\
\text { and } 94 \text { cadmium-copper } \\
\text { alloy workers }\end{array}$ & $\begin{array}{l}\mathrm{Cd}(\mathrm{OH})_{2} \\
\mathrm{Ni}(\mathrm{OH})_{2}\end{array}$ & Excess cancer of nasopharynx (nickel?) \\
\hline Holden (37) & $\begin{array}{l}347 \text { cadmium-copper alloy } \\
\text { workers and } 624 \text { vicinity } \\
\text { workers }\end{array}$ & $\mathrm{CdO}$ (fume) & $\begin{array}{l}\text { Excess deaths from pulmonary disease } \\
\text { (not cancer), elevated risk of lung cancer } \\
\text { in vicinity workers (arsenic?, smoking?) }\end{array}$ \\
\hline $\begin{array}{l}\text { Sorahan \& } \\
\text { Waterhouse (95) }\end{array}$ & $\begin{array}{l}3025 \text { nickel-cadmium } \\
\text { battery workers }\end{array}$ & $\begin{array}{l}\mathrm{CdO} \text { and } \mathrm{Cd}(\mathrm{OH})_{2} \\
\text { dust, } \mathrm{Ni}(\mathrm{OH})_{2}\end{array}$ & $\begin{array}{l}\text { Significant increase in respiratory can- } \\
\text { cer in "highly or moderately" exposed } \\
\text { workers but not in "high-exposure" } \\
\text { group (nickel hydroxide and welding } \\
\text { fumes confounding factors?) }\end{array}$ \\
\hline $\begin{array}{l}\text { Armstrong \& } \\
\text { Kazantzis (3) }\end{array}$ & $\begin{array}{l}6995 \text { male cadmium } \\
\text { workers of } 17 \text { different } \\
\text { plants }\end{array}$ & $\begin{array}{l}\text { CdO dust and fume, } \\
\text { CdS, dust from } \\
\text { Cd stabitizers }\end{array}$ & $\begin{array}{l}\text { Significant excess of lung cancers in } \\
\text { the "always low" exposure group only, } \\
\text { probably not related to cadmium; high } \\
\text { risk of dying from bronchitis in "ever } \\
\text { high" exposure group }\end{array}$ \\
\hline $\begin{array}{l}\text { Elinder et al (17) } \\
\text { [update of study by } \\
\text { Kjellström et al (46)] }\end{array}$ & $\begin{array}{l}522 \text { workers of cadmium- } \\
\text { nickel battery factory }\end{array}$ & $\begin{array}{l}\text { CdO dust, } \\
\left.\mathrm{Ni}(\mathrm{OH})_{2}\right)\end{array}$ & $\begin{array}{l}\text { Insignificant increase in lung cancer ( } 8 \\
\text { observed, } 6 \text { expected); one cancer of na- } \\
\text { sopharynx (nickel?) }\end{array}$ \\
\hline $\begin{array}{l}\text { Thun et al (101) } \\
\text { [update of study by } \\
\text { Lemen et al (49)] }\end{array}$ & $\begin{array}{l}602 \text { cadmium production } \\
\text { workers }\end{array}$ & $\begin{array}{l}\text { CdO dust and fume, } \\
\mathrm{CdSO}_{4}, \mathrm{CdS} \text { (some As) }\end{array}$ & $\begin{array}{l}\text { Lung cancer incidence increased signifi- } \\
\text { cantly with cumulative exposure; smok- } \\
\text { ing and arsenic exposure did not ac- } \\
\text { count for increase }\end{array}$ \\
\hline $\begin{array}{l}\text { White et al (106) } \\
\text { (abstract only) }\end{array}$ & $\begin{array}{l}672 \text { cadmium production } \\
\text { workers (same plant as in } \\
\text { Thun et al study) }\end{array}$ & $\begin{array}{l}\mathrm{CdO} \text { dust and fume, } \\
\mathrm{CdS}, \mathrm{CdSO}_{4} \text { (some As) }\end{array}$ & $\begin{array}{l}\text { No excess lung cancer due to cadmium } \\
\text { when corrected for personal smoking } \\
\text { history and arsenic exposure }\end{array}$ \\
\hline
\end{tabular}

a $\mathrm{CdO}=$ cadmium oxide, $\mathrm{Cd}(\mathrm{OH})_{2}=$ cadmium hydroxide, $\mathrm{Ni}(\mathrm{OH})_{2}=$ nickel hydroxide, $\mathrm{As}=$ arsenic, CdS = cadmium sulfi.de, $\mathrm{Cd}=$ cadmium, $\mathrm{CdSO}_{4}=$ cadmium sulfate. 
cinogenicity of inhaled cadmium can be drawn from this study.

Sorahan \& Waterhouse (95) conducted a prospective mortality study of 3025 nickel-cadmium workers. They classified cadmium exposure as "high," " moderate," and "minimal" exposure and grouped the workers by cumulative duration of employment in a "high-exposure job" and in a "high- or moderateexposure job." Data on smoking history were not available. In the "high- or moderate-exposure job" group a significant risk of lung cancer was noted. Since a significant risk was not found for the "high-exposure job" group, the authors discussed oxyacetelene in welding fumes, to which the moderately exposed workers were exposed, as a confounding factor. Nickel hydroxide dust could have been another confounding factor although the high-exposure group was also exposed to this dust and no significant increase in lung cancer was found for this group. Alternatively, the authors reasoned that exposure to cadmium oxide could indeed have been a risk factor which failed to show in the highexposure group because of the low number of cases. Thus no firm conclusions about the pulmonary carcinogenicity of inhaled cadmium can be drawn from this study.

Armstrong \& Kazantzis (3) included 6995 male British cadmium workers from 17 different plants in a large cohort mortality study. They divided the cohort into "always low" exposure, "ever medium," and "ever high" exposure, without specifying the actual cadmium concentrations in the air to which these workers were exposed. The "ever high" group consisted of only 199 workers. Exposure was to a variety of cadmium compounds, such as cadmium oxide (dust and fume), cadmium sulfide dust, and dust from cadmium stabilizers. Mortality was compared to the standard mortality ratios for the population of England and Wales, which were adjusted for regional variations. A significant excess of lung cancer was found for the "always low" exposure workers with 10 years or more of work history, whereas such an excess was not found in the "ever medium" and "ever high" exposure groups. The last group exhibited, however, a significantly increased risk of dying from bronchitis. Since there was no increase in lung cancer risk with intensity of exposure, the authors concluded that it was unlikely that the excess in the "always low" group was due to cadmium. Since exposure to the different cadmium compounds was not considered separately, a more-detailed analysis taking into account personal exposure history according to cadmium compound would possibly be helpful. Very recently, Kazantzis et al (43) concluded from their evaluation of lung cancer cases among workers of a lead-zinc-cadmium smelter that " further analysis associated with 10 years employment at each exposure level suggested an increasing lung cancer risk with increasing level of exposure to arsenic and to lead, but not to cadmium, zinc, $\mathrm{SO}_{2}$ [sulfur dioxide] or dust."
Elinder et al (17), in an update of an earlier study, reported on cancer mortality among 522 workers of a Swedish cadmium-nickel factory. The workers had been exposed to cadmium oxide dust at levels of about $1 \mathrm{mg} / \mathrm{m}^{3}$ before 1947 , about $0.3 \mathrm{mg} / \mathrm{m}^{3}$ between 1947 and 1962 , then to lower levels of about $0.05 \mathrm{mg} / \mathrm{m}^{3}$ and since 1975 to about $0.02 \mathrm{mg} / \mathrm{m}^{3}$. The air concentrations of nickel hydroxide had been $2-10$ times higher than those of cadmium oxide. The standard mortality ratio for lung cancer was 133 , with eight observed versus six expected cases. Although this value was not significant, the authors suggested an association between lung cancer and exposure to cadmium based on a combination of the results of all available epidemiologic data. They also stressed the need to study the influence of simultaneous exposure to other pollutants, in particular nickel hydroxide.

Recently, Thun et al (101) published an update of the study by Lemen et al (49). The study was extended to include 602 workers who had been employed at the cadmium production plant between 1940 and 1969 for at least six months. Exposure was to cadmium oxide (as dust and fume), cadmium sulfate, and cadmium sulfide. The vital status of the workers was determined through 1978 . When cause-specific mortality rates were compared to rates of a modified life-table system developed by NIOSH, it was found that mortality from respiratory cancer was significantly increased among the cadmium workers employed for two or more years. This determination was based on 16 lung cancer cases observed versus seven expected. The authors also grouped 576 workers hired on or after January 1926 according to cumulative exposure to cadmium and showed that lung cancer mortality increased with increasing cumulative exposure. The result was significant for workers who exceeded $2920 \mathrm{mg}$-days $/ \mathrm{m}^{3}$. This group had a standard mortality ratio (SMR) of 280. The authors calculated that the cumulative exposure of this group was equivalent to a time-weighted average (TWA) exposure level of more than 200 $\mu \mathrm{g} / \mathrm{m}^{3}$ for 40 years. Lung cancer mortality among workers with a 40-year TWA exposure of $41-200$ $\mu \mathrm{g} / \mathrm{m}^{3}$ showed a $50 \%$ increase (SMR 152, not significant), and for exposure below $40 \mu \mathrm{g} / \mathrm{m}^{3}$ the SMR was 100. The standardized rate ratios were significantly correlated with cumulative exposure $(\mathrm{p}=0.0001)$. The authors of this study also tried to take arsenic exposure into account by using measurements of arsenic concentrations made in certain areas of the plant and a risk assessment model for arsenic developed by the Occupational Safety and Health Administration. Likewise, the influence of smoking was estimated from information on the smoking habits of the cadmium workers on a questionnaire collected from approximately $70 \%$ of the survivors or next of kin. Each of these two confounding factors alone could not account for the observed excess lung cancer mortality. A reported multiplicative effect of arsenic exposure plus smoking on lung cancer (76) was not evaluated in this study. 
On the other hand, Welch et al (105) found no evidence of such interaction between arsenic exposure and smoking. Thus the study by Thun et al (101) represents the best evidence so far for a respiratory carcinogenic effect of inhaled cadmium on humans.

Using a slightly enlarged cohort of the same workers as those in the Thun et al (101) study, White et al (106) arrived at a different conclusion. Using data on the smoking habits of the workers and on the arsenic content of the plant feed material provided by the company and correcting for these confounding factors, they claimed that lung cancer due to cadmium exposure was not significantly elevated in their cohort. A significant association for lung cancer was found with respect to cigarette smoking and employment of two or more years. No detailed analysis of the data has yet been published. In an attempt to solve this controversy, Lamm (47) pointed out methodological problems associated with the two studies. He proposed to analyze the cohorts by date of hire rather than by date of employment in a particular work area in order to take into account changing arsenic levels. In addition, he pointed out that cigarette smoking history and its effects should also be reanalyzed.

The Thun et al study (101) is the only published detailed report suggesting that inhaled cadmium is a human lung carcinogen, and it confirms the earlier findings by Lemen et al (49) in a subgroup of the same worker cohort. Applying the criteria of the International Agency for Research on Cancer (39), the Carcinogen Assessment Group of the US Environmental Protection Agency (EPA) concluded that overall the evidence is limited that inhaled cadmium is a human lung carcinogen (28). The EPA estimated a unit risk for lung cancer due to cadmium exposure, based on the Thun et al study, to be $1.8 \times 10^{-3}(21)$. The unit risk is defined as the incremental cancer risk from lifetime exposure to a concentration of $1 \mu \mathrm{g}$ of the pollu$\tan t / \mathrm{m}^{3}$ of air.

\section{Animal studies}

The development of lung tumors in rats was an unexpected finding in a study concerning the behavioral effects of inhaled cadmium in one study (32). Ten rats had been exposed to a cadmium (as cadmium chloride) concentration of $20 \mu \mathrm{g} / \mathrm{m}^{3}$ for 18 months. Subsequent macroscopic and microscopic examination of the lungs showed that five of these animals had developed lung tumors, including four adenomas and one adenocarcinoma. On the basis of this surprising result, a moredetailed study was designed to elucidate further the carcinogenic potency of inhaled cadmium chloride. After 18 months of continuous exposure of 40 rats each to a cadmium (as cadmium chloride) concentration of $12.5,25$, and $50 \mu \mathrm{g} / \mathrm{m}^{3}$ (mass median aerodynamic diameter of particles $0.55 \mu \mathrm{m}$ ) and after an additional
13 months of observation, primary lung carcinomas were found in a classic "exposure concentrationresponse" manner (figure 1). At an exposure concentration of $12.5 \mu \mathrm{g} / \mathrm{m}^{3}, 15.4 \%$ of the animals had developed lung carcinomas. At $25 \mu \mathrm{g}$ it was $52.6 \%$, and at $50 \mu \mathrm{g} / \mathrm{m}^{3}$ the percentage was $71.4(99)$. None of the control animals developed lung tumors. The mean cadmium concentration in the lungs of the three exposed groups at the end of the 13-month observation period was 5.6, 4.7, and $10.4 \mu \mathrm{g}$ of cadmium/g of lung, respectively; in the controls it was less than $0.03 \mu \mathrm{g} / \mathrm{g}$. Histologically, the experimentally induced tumors were adenocarcinomas, epidermoid carcinomas, mucoepidermoid carcinomas and combined epidermoid and adenocarcinomas. According to a personal communication from Takenaka, the appearance of numerous type II like alveolar cells in most of the tumors places their origin in the peripheral lung. So far, this study represents the only conclusive experimental evidence that cadmium inhaled at low concentrations (as cadmium chloride aerosols) can induce malignant lung tumors.

In another inhalation study, 61 rats were exposed for $30 \mathrm{~min}$ to cadmium oxide at the very high concentration of $60 \mathrm{mg} / \mathrm{m}^{3}(30)$. Of the 34 animals surviving for one year, one had developed an adenocarcinoma in the lung, a finding which was not significant. The carcinogenicity of cadmium oxide was also evaluated by intratracheal instillation of the compound into male rats (89). Small particles of cadmium oxide (count median diameter $0.5 \mu \mathrm{m}$ ) suspended in saline were instilled intratracheally at a dose of $25 \mu \mathrm{g}$ either once, twi$\mathrm{ce}$, or three times at weekly intervals. Two rats out of 48 in the high-dose group developed lung tumors (adenocarcinomas), a finding which was not statistically significant. There was, however, a significant increase in mammary tumors. The failure to induce a significant increase in lung tumors was probably related to

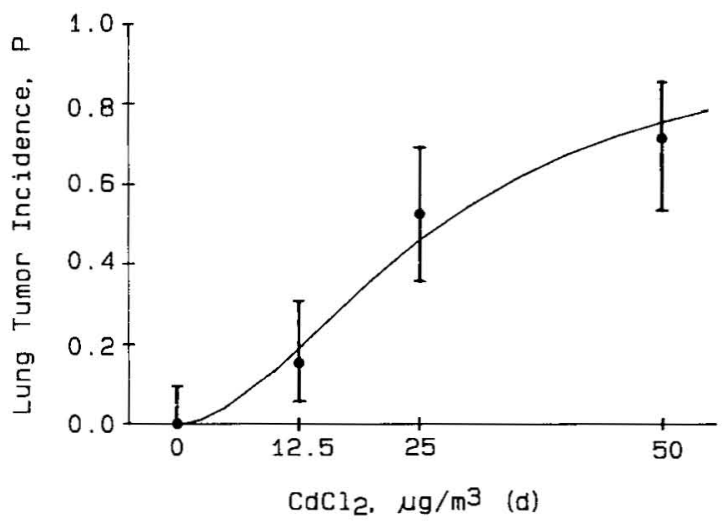

Figure 1. Exposure concentration-response curve for the induction of lung tumors in rats after chronic exposure to cadmium chloride $\left(\mathrm{CdCl}_{2}\right)$ aerosols (99). The vertical bars represent the $95 \%$ confidence intervals of the data points. A logit model fitted the data best: $P=1 /[1+\exp (-(-6.15+1.86$ In d)!]. 
the method of administration since $80 \%$ of an instilled cadmium oxide dose has been found to be rapidly eliminated at a rate of $17 \% / \mathrm{h}(31)$.

Thus, according to criteria set up by the International Agency for Research on Cancer (39), sufficient evidence of pulmonary carcinogenicity of inhaled cadmium in animals is only provided by the study by Takenaka et al (99), which used cadmium chloride aerosols. This finding has to be confirmed in other species and for other cadmium compounds. Presently, such studies are underway, and Oldiges \& Glaser (73) recently reported preliminary results which indicate that, in addition to cadmium chloride, other inhaled cadmium compounds (cadmium oxide, cadmium sulfate, cadmium sulfide) can induce lung carcinomas in rats. With the application of a logit analysis to fit the experimental data of the study by Takenaka et al (99), lung tumor incidence $P$ in rats exposed to cadmium chloride can be described by

$P=1 /[1+\exp \{-(-6.15+1.86 \ln d)\}]$,

where $d$ is the exposure concentration in micrograms per cubic meter (figure $1, \chi^{2}=1.3$ for goodness of fit with one degree of freedom). Calculation of a unit risk $\left(P\right.$ per $\left.1 \mu \mathrm{g} / \mathrm{m}^{3}\right)$ gives a value of $2.13 \times 10^{-3}$. Although this value is not much different from what the EPA has estimated for humans on the basis of the study by Thun et al (101), it is questionable whether this number from the rat study is of practical value for human exposure since it is based on only 18 months of exposure of rats and since the same external exposure $(d)$ will not lead to equivalent deposited doses in bronchial and alveolar regions of the respiratory tract of rat and man. Even extrapolation to lifetime exposure of the rat - a mathematical exercise with many assumptions - would result in a quantitative description of the correlation "inhaled concentrationresponse" valid for the rat only, and it should not be directly applied to humans for reasons discussed in the following section.

\section{Extrapolation of pulmonary effects of cadmium from animals to man}

As discussed before, evidence from epidemiologic studies is limited that inhaled cadmium, possibly cadmium oxide, is a human lung carcinogen. A comparison of the results of the rat study and the epidemiologic studies seems to show that rats are more sensitive to the carcinogenic effects of inhaled cadmium than humans. This possibility raises the question of whether the results from the rat study should or can be extrapolated to humans. A well-controlled laboratory study of rats is obviously quite different from human exposure conditions, and many factors have to be considered when attempts are made to extrapolate pulmonary effects of chronic cadmium exposure from animals to man.
Particle size is one such factor, since it determines the site of deposition and consequently the target cells. The cadmium chloride particles used in the rat study (99), with a mass median aerodynamic diameter of 0.55 $\mu \mathrm{m}$, were mostly deposited in the periphery of the lung so that the alveolar region received the highest dose (83). Particle sizes were not reported in the epidemiologic study by Thun et al (101). However, from the description of the plant operation by Smith et al (92), it becomes evident that the sizes of cadmiumcontaining particles at different production sites must have varied over a wide range. The median particle sizes in areas with cadmium oxide dust exposure were presumably around $2-3 \mu \mathrm{m}$, whereas freshly generated cadmium oxide fume consists of submicronic particles. Deposition of the larger particles is greater in the conducting airways (60). Since man, unlike the rat, is not an obligatory nose-breather, bronchial deposition is enhanced during mouth breathing when the filtering capacity of the nose is not present. On the other hand, the dose to the bronchial tissue is much less when submicronic particles are inhaled. Thus the target cells receiving a high dose of cadmium were possibly quite different in the rat and human studies. This difference may be reflected in the histological types of the tumors, which - as far as determined - were mostly of bronchogenic origin in the study of Thun et al and mostly of bronchoalveolar origin in the rat study. Therefore, it would be of interest to group and analyze the cohort of cadmium workers not only by duration of employment and level of exposure but also by production site, which determines the size of the cadmium-containing particles during exposure. Although bronchially deposited particles are generally cleared within 24 h by mucociliary movement, an impairment of ciliary clearance by cadmium is possible (1). This effect can also be inferred from the high incidence of chronic bronchitis found in cadmiumexposed workers (3). Retarded bronchial clearance will increase the retention of cadmium and consequently the dose to the bronchial epithelium. The dissimilarities of the histological cell types of the observed tumors in rats and humans demonstrate, however, that more than one cell type in the respiratory tract is sensitive to the carcinogenic effects of cadmium.

Another factor that has to be considered when the two studies are compared is the chemical form of inhaled cadmium. It is conceivable that water solubility may affect the toxic effects of a cadmium compound in the lung. However, cadmium oxide (poorly soluble in water) and cadmium chloride (very soluble in water) were found to be equally toxic to the lung $(24,68)$, and thus water solubility does not appear to be a good predictor of lung toxicity. Rapid solubilization of cadmium oxide does occur in the lung (31), possibly due to the uptake of the cadmium oxide particles by alveolar macrophages and subsequent exposure to the low $\mathrm{pH}$ within the phagolysosome. Dose-dependent phagolysosomal solubilization was demonstrated for man- 
ganese dioxide by Lundborg et al (53), and this process is conceivably dependent on particle size.

My co-workers and I had also found that long-term lung retention of inhaled cadmium chloride and cadmium oxide is not different (67), a finding which also suggests that the solubility and metabolism of cadmium deposited in the lung can be independent of water solubility of the administered compound. The water solubility of cadmium oxide $(\sim 0.5 \mathrm{mg} / 100 \mathrm{ml}$ at room temperature) alone may account for a significant fraction of the deposited cadmium oxide solubilized in the lung. The large alveolar surface area $\left(75 \mathrm{~m}^{2}\right)$ and the thickness of the alveolar lining fluid ( $\sim 0.2 \mu \mathrm{m})(94)$ represent a fluid volume of $\sim 15 \mathrm{ml}$, in which $\sim 75 \mu \mathrm{g}$ of cadmium oxide can be dissolved. This amount would be equivalent to inhaling an air concentration of cadmium oxide of $30 \mu \mathrm{g} / \mathrm{m}^{3}$ over an 8 -h workday, on the assumption of $10 \mathrm{~m}^{3}$ of air inhaled with a 25 $\%$ deposition of cadmium oxide particles $1 \mu \mathrm{m}$ in diameter. In addition, it is conceivable that the rate of cadmium oxide solubilization in the lung is increased after phagocytosis by macrophages - as reported for manganese dioxide (53) - since cadmium oxide is soluble in acids. Because in vivo solubility of a cadmium compound in the lung is greater than its in vitro solubility in water, the terms "solubility" or "soluble" should be adequately defined when toxic effects of inhaled cadmium-containing particles are characterized. The in vivo solubility of cadmium compounds differs. With regard to cadmium sulfide, for example, it was found that either 10 -fold higher concentrations than those of cadmium oxide and cadmium chloride were needed to produce the same effects in the lung (24) or an equal dose to the lung induced significantly less acute effects (68). If in vivo solubility is important for the toxic effects, it implies that the cadmium ion is the toxic agent. Thus certain cadmium compounds may have to be judged differently with regard to the extent of their pulmonary effects.

Species differences could exist regarding the metabolism of cadmium in the lung, such as the induction of metallothionein, which may be important for cadmium retention. Unpublished results from the laboratory in which I work indeed show that retention halftimes of inhaled cadmium chloride in the lungs of rats and nonhuman primates differ considerably. After the inhalation of ${ }^{109}$ cadmium chloride aerosols by rats and monkeys (particle size $\sim 0.8 \mu \mathrm{m}$ ) the biological half-time of pulmonary cadmium was about $75 \mathrm{~d}$ in rats and about $780 \mathrm{~d}$ in monkeys. Continuous longterm exposure to cadmium aerosols at low concentrations $\left(10 \mu \mathrm{g} / \mathrm{m}^{3}\right)$ did not affect the pulmonary retention half-time of cadmium (69). The difference in pulmonary retention will lead to differences in cadmium accumulation in the lungs of these two species during long-term exposure. While the absolute amount accumulating in the lungs will be larger in monkeys, the relative rate of accumulation to equilibrium will be slower in the primate lung than in the rat lung (figure
2 ). It could thus be argued that the rate of cadmium accumulation and the turnover of cadmium in the lung is of importance for its carcinogenic effect. This situation would imply that the rat is the ideal model with which to study the induction of lung tumors by the inhalation of cadmium.

Additional differences that have to be taken into account when the results of the epidemiologic and rat studies are compared are the periodicity of exposure and exposure to other contaminants. Workers may be exposed $8 \mathrm{~h}$ a day. The rats in the study by Takenaka et al (99) were exposed 23 h continuously per day, exposure resembling that of the environment rather than that of the workplace. Lack of a recovery period increases the accumulation of cadmium in the lung and may influence detoxification processes. Exposure of the workers to other pollutants may also influence carcinogenicity. For example, it has been shown that simultaneous subcutaneous injection of cadmium and zinc salts inhibits or prevents the carcinogenic effect on the testes and injection sites of cadmium chloride when administered alone $(26,27)$. It is unknown whether this phenomenon would also be true for inhalational exposure.

The foregoing discussion points out some of the difficulties encountered in the interpretation of the results of experimental long-term inhalation studies. In spite of these difficulties, the finding of a positive correlation between inhalation exposure to low concentrations of cadmium chloride and the induction of lung carcinomas in rats should not be dismissed as irrelevant for extrapolation to humans. Both are mammalian species sharing many basic physiological and biochemical mechanisms. Although differences in the metabo-

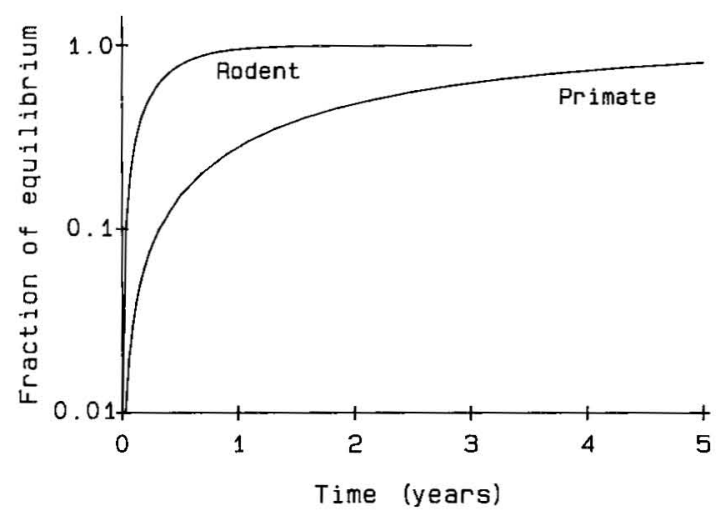

Figure 2. Calculated relative accumulation rates of cadmium in the lungs of rats and monkeys during constant low-level exposure to cadmium chloride aerosols based on the measured lung retention of cadmium chloride in the two species. Due to the larger lung and larger inhaled volume, the absolute amount of cadmium in total lung at equilibrium will be much greater in the primate than in the rodent. At a particle size of $1 \mu \mathrm{m}$ and a concentration of $1 \mu \mathrm{g} / \mathrm{m}^{3}$ air, the equilibrium cadmium value per gram of lung will be $1.1 \mu \mathrm{g}$ for the rodent lung and $3.8 \mu \mathrm{g}$ for the primate lung. 
lism and effects of toxicants are known to exist between rat and man - for example, with regard to arsenic toxicity and carcinogenicity - qualitatively the result of the rat study should be extrapolatable to humans. The necessity to perform animal studies for the detection of carcinogens and general aspects for extrapolation to humans has been discussed by several authors $(35,84)$. Thus, if calculations quantifying a carcinogenic risk associated with human cadmium exposure based on the rat study are attempted, their limitations have to be kept in mind.

\section{Populations at risk}

Persons who are engaged in the production and manufacture of cadmium and cadmium compounds in occupational settings are probably at the highest risk of exposure to airborne cadmium. The numbers of persons working in such industries are not available for most countries; however, NIOSH (63) estimated that about 1.5 million US workers may be potentially exposed to cadmium in some form, and approximately 100000 were identified with exposure to specific cadmium compounds. As discussed before, the solubility of cadmium compounds in the lung probably determines their acute toxic effects. Since this solubility can be different for different cadmium compounds, the resulting bioavailability of cadmium from these compounds to target cells of the respiratory system can also be different. This possibility is often overlooked when effects of exposure to "cadmium" are considered. It is likely that occupational exposure to cadmium oxide dust or fumes constitutes the same risk with regard to developing lung cancer as exposure to soluble forms of cadmium, like cadmium chloride. In the US, federal regulations permit exposure levels of $0.2 \mathrm{mg} / \mathrm{m}^{3}$ for cadmium dust and $0.1 \mathrm{mg} / \mathrm{m}^{3}$ for cadmium fumes. According to the study by Thun et al (101) persons working under those conditions for years may be at an increased risk to develop lung cancer. Levels in other countries are often lower, $0.05 \mathrm{mg} / \mathrm{m}^{3}$.

On the other hand, it can be argued that workers exposed to cadmium sulfide in respective industries are not at the same risk since the cadmium in cadmium sulfide is less bioavailable, as judged from acute and subacute animal experiments. However, while differences of the acute and subacute pulmonary effects between cadmium chloride and cadmium oxide on the one hand and cadmium sulfide on the other have been demonstrated, chronic effects of cadmium sulfide cannot be predicted with certainty at present. Therefore, as long as it has not been shown in well-defined, longterm studies, or in epidemiologic studies, that the effects of cadmium sulfide are different from those of cadmium oxide or cadmium chloride, workers exposed to the present high standard of the US Occupational Safety and Health Administration - which does not differentiate between different cadmium compounds - should be regarded as being at an increased risk.

With regard to the general population, there may be a small risk for persons living in the immediate vicinity of cadmium-emitting industries, in particular smelting operations, which are estimated to emit about $87 \%$ of the total environmental cadmium (92). In these areas annual average airborne cadmium levels may be about $35 \mathrm{ng} / \mathrm{m}^{3}(12)$. Based on the EPA risk estimate (21), the lifetime risk to die of lung cancer due to cadmium exposure would be $6.3 \times 10^{-5}$ for persons living there, a very low value. This risk is due to the directly-emitted cadmium in the ambient air; in addition there is also the resuspension and inhalation of accumulated cadmium-contaminated dust within the household. People possibly at such risk only comprise a very small group; yet no data are available to allow an estimate of their numbers. Since the aforementioned risk estimate is based on occupational exposures, its use for environmental cadmium exposure may be questionable. Particle sizes and deposition behavior of the cadmium-containing particles in the respiratory tract could be quite different in occupational and environmental exposure. Particular attention should also be given to very young children growing up in the vicinity of cadmium-emitting industries. No data on the effects of cadmium on the growing lung have been published, and a person's age at first exposure to cadmium may be an important factor for the development of chronic effects, including lung cancer.

Incineration of municipal wastes and recycling of cadmium-plated scrap can be other sources of exposure to cadmium in the ambient air, and one estimate puts the number of people exposed from this source at $50000(91)$. Nevertheless, concentrations measured in one of these areas, although significantly elevated, were still low $\left(7.7 \mathrm{ng} / \mathrm{m}^{3}\right)(107)$ and would increase the lung burden of cadmium per day far less than the smoking of one cigarette per day. Thus the risk of acquiring lung cancer due to cadmium in the ambient air for this part of the population is so low - on the order of 1 per 100000 - that it can probably be classed as negligible according to a Royal Society study group cited by Doll \& Peto (16). It follows that there is also no risk for the rest of the population living in urban and rural areas with ambient cadmium concentrations at or below the nanogram per cubic meter range.

Another group at risk from increased exposure to cadmium may be smokers. Cigarettes contain varying amounts of cadmium depending on the origin of the tobacco used $(59,77)$. On the assumption of a cadmium content of $1.6 \mu \mathrm{g} /$ cigarette, $10 \%$ being inhaled with mainstream smoke $(5,18)$ and $50 \%$ being deposited (34), a one-pack-per-day smoker may deposit an average of $1.6 \mu \mathrm{g}$ of cadmium per day. This amount is about the same as that deposited in the lungs of a person living in an environment with a continuous air concentration of cadmium of $250 \mathrm{ng} / \mathrm{m}^{3}$, a highly 
polluted area. Based on the EPA risk estimate (21), this figure represents a lifetime risk for lung cancer of about $4.5 \times 10^{-4}$. Since nothing is known about the combined effect of inhaled cadmium with other carcinogens and since cigarettes contain numerous carcinogenic compounds, it is impossible at present to judge to what extent cadmium in cigarettes contributes to the well-established risk of smokers becoming victims of lung cancer.

\section{Interaction with other pollutants}

Human exposure to airborne cadmium almost never occurs alone. Man is always exposed to a complex mixture of compounds. In smelting operations, cadmium is produced from ores containing zinc, copper, lead, or mercury. Other environmental pollutants, both gaseous and particulate, are always present. Several experimental studies have dealt with the interactions of cadmium and other heavy metals like zinc, copper, and selenium (100). Combined administrations of these metals to experimental animals often resulted in a decrease of the toxic effects of cadmium when administered alone. However, most of the studies were concerned with organ systems other than the lung, and only a few experiments dealt with the respiratory tract as a target organ. Even fewer investigators studied combined effects of cadmium and other metals on tumor formation, and nothing has been reported specifically on how other pollutants may affect lung tumor induction by inhaled cadmium.

Of special importance is the combined inhalation of zinc and cadmium since cadmium is generally produced as a by-product during the smelting of zinc ores. A protective or antagonistic action of zinc on cadmium toxicity, including the immune system, has been described $(54,90)$, and this action was also found for pulmonary cadmium effects. For example, zinc was able to protect against increases in bioelectrical conductance induced by cadmium in the trachea (97). My co-workers and I found that the impairment of alveolar clearance after subchronic cadmium oxide exposure of $10 \mu \mathrm{g} / \mathrm{m}^{3}$ could be prevented by simultaneous zinc oxide exposure of $250 \mu \mathrm{g} / \mathrm{m}^{3}$ (71). The underlying mechanism may be an increased induction of metallothionein by zinc. Metallothionein would then be available for binding cadmium since cadmium has a higher binding affinity; zinc in turn is much more rapidly cleared from the lung than cadmium (70).

With regard to tumor induction, it has been shown in subcutaneous injection experiments that the simultaneous administration of zinc acetate $(1 \mathrm{mmol} / \mathrm{kg})$ and cadmium chloride $(0.03 \mathrm{mmol} / \mathrm{kg})$ prevented or reduced injection site carcinomas and interstitial testicular tumors which developed in rats when cadmium chloride was given alone $(26,27)$. It would be of interest to study whether lung tumor induction by inhaled cadmium is affected similarly by the simultane- ous inhalation of zinc. Reports about an increased frequency of chromosome anomalies in workers exposed to a combination of lead and cadmium or lead, cadmium, and zinc as compared to cadmium exposure alone were summarized recently by Nordberg \& Andersen (66). However, without further experiments, it cannot be deduced from these studies whether combined metal exposures are equivalent to an increased tumor risk.

Workers who are employed in cadmium industries and who are possibly at risk of lung cancer from cadmium may also be exposed to other pollutants. Although nothing is known about their combined effects, some generalized remarks seem to be justified. A frequently encountered pollutant is mainstream cigarette smoke, and it is conceivable that the impaired mucociliary clearance caused by smoking does increase retention of inhaled cadmium in the conducting airways of the lung. There is no evidence from epidemiologic studies so far that smoking and cadmium exposure act in an additive or synergistic way. Reevaluation of present epidemiologic studies could possibly yield more information. On the job, smoking may also increase the cadmium lung burden significantly because of the external contamination of cigarettes and tobacco by fingers and dust (79).

Ozone, nitrogen dioxide, and sulfur dioxide are often elevated in urban and industrial areas. These pollutants are known to cause irritation and inflammation in the respiratory tract, and they affect the immune system $(57,59,64)$. They can react readily with a variety of molecular species to produce reactive compounds (56). To what extent these effects can influence the carcinogenic potency of inhaled cadmium is not known. Likewise, there are no data to support an interaction, possibly synergism, between inhaled cadmium and oxidants on the basis of a suggested formation of nitrosamine in the organism after nitrogen dioxide inhalation (103). The finding of a facilitation of metastasis of existing tumors during long-term lowlevel nitrogen dioxide exposure could be another variant in the interaction of an environmental pollutant with a carcinogen like cadmium (86). Certainly, more research is needed to elucidate the important questions about the combined effects of other pollutants and cadmium on the induction of lung cancer.

\section{Biological and pathogenetic mechanisms}

Injected water-soluble and water-insoluble cadmium compounds have been found to be carcinogenic, as mentioned before. Tumors developed both at injection sites and in remote organs such as testes and the pancreas in rats and mice $(26,80)$. The carcinogenic activity of cadmium in certain compounds was further demonstrated by the finding of a high lung tumor incidence in rats exposed to cadmium chloride by inhalation (99) and was further implied by the suggestive 
evidence that inhaled cadmium oxide induces lung tumors in humans (101). However, the underlying molecular mechanism of cadmium carcinogenicity is little understood.

Almost nothing is known about specific events leading to the carcinogenic action of cadmium in general let alone of its action in relation to the lung in particular. Therefore, the following discussion is only intended to outline possible mechanisms leading to the carcinogenic action of cadmium. The carcinogenic activity of chemicals is thought to be based on the fact that most, if not all, chemical carcinogens are strong electrophilic reactants and, as such, interact with essential cellular components (58). They can react with a number of nucleophilic sites in deoxyribonucleic acid (DNA), ribonucleic acid (RNA), and proteins, and this reaction is consistent with both the genetic and epigenetic mechanisms of carcinogenesis. It was found that cadmium does interact with DNA $(40,102,104)$, and the interaction suggests that a genotoxic mechanism is possible. According to these studies, two kinds of binding sites for cadmium exist in DNA, with low and high affinities to the phosphate moieties of DNA, and cadmium has to be available in the ionic form to react with DNA.

Cadmium compounds soluble in the lung will bind readily to proteins, including the low molecular-weight protein metallothionein. The binding of cadmium to metallothionein and other proteins protects the cell from the cytotoxic effects of cadmium. However, the cadmium sensitivity of different cells can vary significantly. Enhanced cellular uptake of cadmium, rather than a deficiency in cellular metallothionein synthesis, could be responsible for this phenomenon (20). Under such conditions of enhanced uptake, more cadmium could conceivably reach the nucleus and react with DNA. There may be a carrier mechanism for bound cytoplasmic cadmium to enter the nucleus, where it can be released and interact with DNA (40). A model incorporating metallothionein as a carrier for cadmium to the nucleus was proposed by Cherian \& Nordberg (10). A carrier mechanism has also been proposed by Costa et al (13) to explain the observed concentration-dependent activity of metal sulfide particles to transform Syrian hamster embryo cells after the particles have been phagocytized. These authors hypothesized that after phagocytosis, which is highly dependent on surface charge, particles are slowly solubilized so that the resulting metal ions in the cytoplasm can interact with oncogenically relevant binding sites. These sites could be molecules leaving the nucleus, such as RNA, or the metal ions could enter the nucleus directly to bind with DNA.

Although Costa et al (13) discussed this mechanism mainly for nickel sulfide, they studied other metal sulfides as well and found that phagocytized cadmium sulfide also has a potent transforming activity in $\mathrm{Sy}$ rian hamster embryo cells. In the lung, alveolar macrophages are the main source for the phagocytosis of particles, but these differentiated cells cannot be transformed to cancerous cells. Macrophages, however, can dissolve cadmium-containing particles, and after their death, due to the cytotoxicity of cadmium, they can be a source of ionic cadmium and of reactive intermediates for interaction with other target cells (13). In addition, type I epithelial cells are also capable of endocytosing small particles $(96,98)$, and the uptake of small particles by cells of the bronchial epithelium has been described (96). Whether slow solubilization processes occurring in these cells initiate the same events as proposed by Costa et al (13) remains to be shown. Bronchial cells, however, are probably the main target cells for cadmium-induced lung cancer in humans.

One of the important factors in this hypothesized mechanism is the presence of cadmium in the ionic form. While this occurrence is the most likely for water-soluble cadmium compounds and for cadmium oxide, it has not been well established for cadmium sulfide particles in the lung. However, the induction of metallothionein in lung tissue after cadmium sulfide inhalation exposure (24) strongly points to some degree of solubilization of cadmium sulfide in the lung, a phenomenon which is also supported by the in vitro studies of Costa et al (13). Because of differences in crystalline structure and also in solubility between calcined and noncalcined cadmium sulfide particles both encountered in occupational exposure - their biological activity may also differ. This possibility needs to be investigated further. An observed protective acion of zinc and magnesium on cadmium-induced tumors $(26,80)$ could be explained by the competitive binding of these metals and cadmium with DNA (102, 104). In order to be effective as antagonists in cadmium carcinogenicity, a large excess of the competing metal appears to be critical.

The possibility of an endocrinologic mechanism in cadmium carcinogenicity should also be taken into account. It was demonstrated that the content of interstitial cell-stimulating hormone (ICSH), a possible tumor promoter, in the pituitary gland was higher after the injection of a dose of cadmium that produced testicular tumors (26). Likewise, Chandler et al (9) showed that cadmium inhibits testosterone release and increases circulating levels of ICSH. Whether these occurrences played a role in the reported induction of testicular tumors in rats $(26,27,80)$ or whether it will even influence the induction of lung tumors by cadmium cannot be assessed at present. It shows, however, that a hormonal mechanism should be considered in tumor induction by cadmium.

It is conceivable that the amount of cadmium retained in the lung is important in the pathogenesis of lung tumors. The retention half-time of cadmium chloride in the primate lung is much longer than in rat lung. However, it is not known whether the prolonged retention - which reflects cadmium in peripheral lung tissue - really poses an increased risk since cad- 
mium during this long retention phase is very likely bound to proteins and may not be bioavailable to the target cells. The target cells in human lung cancer cases are probably bronchial cells, and cadmium stored in the alveolar interstitial region may not contribute to the dose to bronchial cells. Therefore, cadmium reaching the conducting airway epithelium has to be considered the most important source for cancer induction. This source is maintained by the following mechanisms: (i) direct bronchial deposition of inhaled cadmium-containing particles, mostly larger particles; (ii) cadmium-containing particles cleared from peripheral portions of the lung along the mucociliary escalator, either contained in macrophages (macrophages which die on their way up can release those particles and enzymes) or on the mucous blanket; and (iii) local impairment of mucociliary activity due to disease processes, initiated by, for example, smoking or the toxic effects of cadmium itself. Other air pollutants may also be etiologically involved in the impairment of bronchial clearance mechanisms and could influence indirectly the bronchial dose of cadmium and thus lung cancer pathogenesis by the inhalation of cadmium. In addition blood-borne cadmium could conceivably contribute to cadmium accumulation in bronchial tissue via bronchial circulation, although this occurrence would only be a very minor contribution.

Furthermore, during chronic exposure the irritating effects of inhaled cadmium on the mucosa have to be considered. Inhaled cadmium chloride and cadmium oxide aerosols can induce an inflammatory reaction in the lung with the influx of polymorphonuclear cells and macrophages $(33,61)$. The significantly increased incidence of bronchitis in cadmium workers (3) is also indicative of this effect. Activated inflammatory cells are known to release oxygen-derived radicals (51, 85 ). In addition, lipid peroxidation caused by free radical events may be important to the promotion of tumors initiated by a carcinogen (55). The significance of such events has to be investigated further, in particular since they may occur at the site of the target cells of the bronchial tree during cadmium-induced bronchitis.

\section{Research needs}

Several basic questions remain to be answered before cadmium compounds in general can be classified as human lung carcinogens when inhaled. Until then it would be prudent from a preventive point of view to treat all cadmium compounds as if they had a carcinogenic potential. More studies are needed on the epidemiology of cadmium-induced lung cancer, as well as on long- and short-term experiments with whole animals. Cellular events have to be investigated as well.

With regard to epidemiology, attempts should be made to solve the "cadmium controversy" over whether the evidence is sufficient to classify cadmium as a human lung carcinogen. This controversy arose from differences in interpretation and evaluation of a cancer mortality study $(101,106)$ of workers who had been employed at the same cadmium production plant. $\mathrm{Cu}-$ mulative exposure to cadmium was established for three groups of workers. However, no attempts were made to group workers according to the cadmium compound they were exposed to, ie, cadmium oxide (as dust and as fume), cadmium sulfate, and cadmium sulfide, and possible differences in the carcinogenic potency of these compounds have to be considered. Thus a reevaluation which would take into account personal exposure history data of this cohort should be performed. This reevaluation should include smoking and exposure to other metals (arsenic) in addition to specific cadmium compound exposure.

A similar approach should be attempted with the data of Armstrong \& Kazantzis (3). In their study a very large cohort of cadmium workers was grouped according to low, medium, and high exposure, and the study population was from 17 different plants. An update should group the workers by exposure to specific cadmium compounds such as cadmium oxide (fume or dust), cadmium sulfide, and cadmium dust from stabilizers since such data seem to be available. Other personal histories relevant to the development of respiratory disease, as already mentioned, should be included.

To further the evaluation of specific cadmium compounds in epidemiologic studies and the measurements of concentrations, a determination of particle sizes should be included as an important parameter. While such a determination is impossible retrospectively, measurements under simulated conditions may give an indication of differences in particle sizes encountered historically at different production sites. As already pointed out, knowledge about levels of other metallic and gaseous air contaminants and polynuclear aromatic hydrocarbons (PAH) would also be valuable information.

The quantification of exposure from which estimates of the retained dose in the lung can be made is of prime importance for epidemiologic studies. In addition to measuring airborne concentration and particle sizes, a more direct estimate of personal exposure could be attempted through the determination of cadmium in urine and the in vivo measurement of liver and kidney cadmium with neutron activation analysis (19). Attempts could be made to determine lung cadmium by the same method by choosing a representative area of the lung, possibly the left lung, in which the in vivo measurement of cadmium is not influenced by cadmium of the liver. Because of the extremely long biological half-time of cadmium in the human kidney (23), determination of renal cadmium is a good indicator of past exposures provided there is no kidney damage. Of course, smoking and renal disease, which can either increase (50) or decrease (87) kidney cadmium significantly, have to be taken into account. Cadmium 
translocated to liver and kidney could also be an indicator of the bioavailability of the different cadmium compounds. If autopsy material becomes available, the cadmium content of lung, liver, and kidney should be determined. Attempts should also be made to identify the histological type of tumors found in workers in order to identify the cells of origin.

A major open question that should be dealt with in whole animal experiments concerns the pulmonary carcinogenicity of different chemical forms of cadmium, both water-soluble and water-insoluble compounds. Such experiments have to be long-term inhalation studies, and they cannot be substituted by in vitro studies. Cadmium chloride (representative of a highly soluble compound), cadmium oxide (possibly as aged dust and as freshly generated fume), and cadmium sulfide of approximately the same particle sizes (submicronic) should be inhaled by the animals during most of the life-span. In addition to the rat, at least one other species should be selected, and groups of both sexes should be included (11). Inhaled concentrations should be in a range that would not affect the normal growth and general well-being of the animals. Preliminary results on mortality and lung tumor induction from a study of this design were recently presented by Oldiges et al (73). Although no final data on tumor induction are yet available, the authors reported that lung carcinomas in rats were indeed induced by chronic inhalation of cadmium oxide, cadmium sulfate, and cadmium sulfide, in addition to cadmium chloride.

An interesting question concerns the effects of combined experimental exposure to cadmium aerosols and zinc aerosols because of the demonstrated protective effect of zinc against other cadmium effects and because zinc is often associated with cadmium in smelting operations. Likewise, the combined exposure of cadmium plus known carcinogens like PAH and common gaseous and particulate air pollutants such as nitrogen dioxide and sulfates could be simulated in laboratory studies in order to evaluate cocarcinogenic or synergistic effects. Whether repeated intratracheal instillations of cadmium and cadmium plus another compound (zinc, PAH) can replace the inhalation experiments has to be investigated. Sanders et al (89) could not induce significant numbers of tumors with cadmium oxide when instilled three times at weekly intervals. Possibly, the technique of several repeated instillations could be a less costly method to study the tumorigenic potency of cadmium in combination with other pollutants (88).

It would be important practically to compare the effects of inhaled cadmium chloride given to rats as intermittent exposure $(8 \mathrm{~h} / \mathrm{d})$ to those of continuous 24 $\mathrm{h} / \mathrm{d}$ exposure. This comparison would allow an evaluation of the significance of recovery periods, as discussed in the previous section. Basically, this experiment can be approached in two ways, either by keeping the inhaled concentration constant, which would result in a different deposited dose, or by keeping the total deposited dose constant, which means the inhaled concentration must be changed. The former approach would have just one variable, the exposure time, whereas in the latter both the exposure time and the inhalation concentration are changed. Both methods have advantages and disadvantages which will not be discussed here. The particle-size distribution should be kept the same with either approach.

The effects of inhaled cadmium on the growing lung and the significance of age at first exposure deserve special interest. Experiments designed to start exposure shortly after birth would address this problem, and both acute and chronic effects on cells of the respiratory tract of the growing lung should be investigated.

There is a lack of knowledge regarding lung retention characteristics of cadmium sulfide. These characteristics could differ from those of cadmium oxide because cadmium sulfide appears to have a lower in vivo solubility and therefore is possibly cleared by different mechanisms than cadmium oxide and cadmium chloride. Since there is a significant difference between rodents and primates with regard to the lung clearance of inhaled cadmium chloride, lung retention of cadmium sulfide should also be studied in both species. The distribution of cadmium into other organs, eg, liver and kidney, should be determined in such studies since it would give an indication of the bioavailability of cadmium from inhaled cadmium sulfide.

Besides oncogenic events, the actions of different cadmium compounds, in particular cadmium sulfide, on lung epithelia should be investigated in order to compare their biological activity. Such actions include, for example, the effects on epithelial barrier function (by determining effects on epithelial permeability) and acute and chronic inflammatory reactions induced in the lung by different cadmium compounds. The possibility of lipid peroxidation in the lung after cadmium exposure also deserves attention. In addition, it is very important to study the uptake of cadmium into different types of cells of both the peripheral lung and the bronchial tree. Results may indicate different sensitivities of the different cells to the effects of cadmium. Metallothionein may play a central role in the metabolism of cadmium in the lung since this protein has been shown to be induced in this organ by the inhalation of cadmium aerosols $(72,81)$. Differences in the inducibility of this protein in different cells of the respiratory tract may render them more or less sensitive to the toxic effects of ionic cadmium. To investigate this possibility, one could measure metallothionein induction in bronchial and peripheral lung cells using a histochemical technique (6).

Finally, specific questions regarding the interactions and consequences of cadmium-DNA interaction leading to oncogenic events have to be addressed in in vitro studies designed to elucidate basic mechanisms at a molecular level. 
While these are comprehensive research goals, priorities should be given to the evaluation of epidemiologic studies and to animal inhalation studies in order to answer the more pragmatic question about the pulmonary carcinogenic potency of different cadmium compounds.

\section{Acknowledgments}

I wish to thank my colleagues Drs PE Morrow, D Hochrainer, TW Clarkson, and J Ferin, and Mr S Gavett for reading the manuscript and for their valuable suggestions. I also thank Dr C Cox from the Biometrics Core for the logit analysis of lung tumor incidences for rats.

This paper was partially based on work supported by grants ESO1247 and ES01248 from the National Institutes of Health.

\section{References}

1. Adalis D, Gardner DE, Miller FJ, Coffin DL. Toxic effects of cadmium on ciliary activity using a tracheal ring model system. Environ Res 13 (1977) 111-120.

2. Adamsson E. Long-term sampling of airborne cadmium in an alkaline battery factory. Scand J Work Environ Health 5 (1979) 178-187.

3. Armstrong BG, Kazantzis G. The mortality of cadmium workers. Lancet 1 (1983) 1425-1427.

4. Asvadi S, Hayes JA. Acute lung injury induced by cadmium aerosols. Am J Pathol 90 (1978) 89-98.

5. Bache CA, Lisk DJ, Doss GJ, Hoffmann D, Adams JD. Cadmium and nickel in mainstream particulates of cigarettes containing tobacco grown on a lowcadmium soil-sludge mixture. J Toxicol Environ Health 16 (1985) 547-552.

6. Banerjee D, Onosaka S, Cherian MG. Immunohistochemical localization of metallothionein in cell nucleus and cytoplasm of rat liver and kidney. Toxicology 24 (1982) 95-105.

7. Berengsi G, Nagymajtenyi L. Pulmonary injury of mice produced by chronically peroral treatment with different substances. Zentrabl Bakteriol I Abt Orig B Hyg Krankenhaushyg Betriebshyg Prev Med 164 (1976) 282-287.

8. Buchet JP, Roels H, Bernard A, Lauwerys R. Assessment of renal function of workers exposed to inorganic lead, cadmium, or mercury vapor. J Occup Med 22 (1980) 741-750.

9. Chandler JA, Timms BG, Morton MS, Groom GV. Effect of cadmium administration in vivo on plasma testosterone and ultrastructure of accessory sex organs of the rat. J Endocrinol 69 (1976) $21 \mathrm{P}$.

10. Cherian MG, Nordberg M. Cellular adaptation in metal toxicology and metallothionein. Toxicology 28 (1983) $1-15$.

11. Chu KC, Cueto C, Ward JM. Factors in the evaluation of 200 National Cancer Institute carcinogen bioassays. J Toxicol Environ Health 8 (1981) 261-280.

12. Commission of the European Communities. CEC criteria (dose/effect relationships) for cadmium. Pergamon Press, Oxford, New York, Toronto, Sydney, Paris, Frankfurt 1978.

13. Costa M, Heck JD, Robinson SH. Selective phagocytosis of crystalline metal sulfide particles and DNA strand breaks as a mechanism for the induction of cellular transformation. Cancer Res 42 (1982) 2757-2763.

14. Delos CJ. Cadmium contamination of the environment: An assessment of nationwide risk. Office of Water Regulation and Standards, Washington, DC 1985 (EPA-440/4-85-023).

15. Dervan PA, Hayes JA. Peribronchiolar fibrosis following acute experimental lung damage by cadmium aerosol. J Pathol 128 (1979) 143-149.

16. Doll R, Peto J. Asbestos: Effects on health of exposure to asbestos. Her Majesty's Stationery Office, London 1985.

17. Elinder CG, Kjellström T, Hogstedt C, Anderson K, Spang G. Cancer mortality of cadmium workers. $\mathrm{Br}$ $\mathrm{J}$ Ind Med 42 (1985) $651-655$.

18. Elinder CG, Kjellström T, Lind B, Linnman L, Piscator M, Sundstedt K. Cadmium exposure from smoking cigarettes: Variations with time and country where purchased. Environ Res 32 (1983) 220-227.

19. Ellis KJ, Cohn SH, Smith TJ. Cadmium inhalation exposure estimates: Their significance with respect to kidney and liver cadmium burden. J Toxicol Environ Health 15 (1985) 173-187.

20. Enger MD, Hildebrand CE, Walters RA, Saegrave JC, Barham SS, Hoagland HC. Molecular and somatic cell genetic analysis of metal resistance mechanisms in mammalian cells. In: Tashjian AH Jr, ed. Molecular and cellular approaches to understanding mechanisms of toxicology. Harvard School of Public Health, Boston, MA 1984, pp 39-62.

21. Environmental Protection Agency. Updated mutagenicity and carcinogenicity assessment of cadmium. Washington, DC 1985. (EPA-600/8-83-025F).

22. FAO/WHO Expert Committee on Food Additives. WHO technical report series number 505. World Health Organization, Geneva 1972.

23. Friberg L, Piscator $M$, Nordberg GF, Kjellström T. Cadmium in the environment. Second edition. CRC Press, Cleveland, OH 1974.

24. Glaser U, Hochrainer D, Klöppel H. Pulmonary bioavailability of cadmium aerosols in Wistar rats. N Schmiedeberg's Arch Pharmacol 325 (1984) R-25.

25. Greenspan BJ, Morrow PE. The effect of in vitro and aerosol exposures to cadmium on phagocytosis by rat pulmonary macrophages. Fund Appl Toxicol 4 (1984) $48-57$.

26. Gunn SA, Gould TC, Anderson WAD. Cadmiuminduced interstitial cell tumors in rats and mice and their prevention by zinc. J Natl Cancer Inst 31 (1963) $745-759$.

27. Gunn SA, Gould TC, Anderson WAD. Effect of zinc on cancrogenesis by cadmium. Proc Soc Exp Biol Med 115 (1964) 653-657.

28. Haddow A, Dukes CE, Mitchley BCV. Carcinogenicity of iron preparations and metal-carbohydrate complexes. Rep Br Emp Cancer Campaign 39 (1961) 74.

29. Haddow A, Roe FJC, Dukes CE, Mitchley BCV. Cadmium neoplasia sarcomata at the site of injection of cadmium sulphate in rats and mice. $\mathrm{Br} \mathrm{J}$ Cancer 18 (1964) 667-673.

30. Hadley JG, Conklin AM, Sanders CL. Systemic toxicity of inhaled cadmium oxide. Toxicol Lett 4 (1979) 107-111.

31. Hadley JG, Conklin AM, Sanders CL. Rapid solubilization and translocation of 109-CdO following pulmonary deposition. Toxicol Appl Pharmacol 54 (1980) $156-160$.

32. Heering $H$, Oberdörster G, Hochrainer D, Baumert $\mathrm{HP}$. Learning behavior and memory of chronically $\mathrm{Cd}$ exposed rats and organ distribution of $\mathrm{Cd}$. In: Commission of the European Communities. Health effects of heavy metals. Brussels 1979, pp 61-62. (Doc XII/ENV/64/79). 
33. Henderson RF, Rebar AH, Pickrell JA, Newton GJ. Early damage indicators in the lung: III Biochemical and cytological response of the lung to inhaled metal salts. Toxicol Appl Pharmacol 50 (1979) 123-136.

34. Hinds W, First MW, Huber GL, Shea JW. A method for measuring respiratory deposition of cigarette smoke during smoking. Am Ind Hyg Assoc J 44 (1983) $113-118$

35. Hogan MD. Extrapolation of animal carcinogenicity data: Limitations and pitfalls. Environ Health Perspect 47 (1983) 333-337.

36. Holden H. Cadmium and pulmonary emphysema. Lancet 1 (1980) 1137.

37. Holden H. Further mortality studies on workers exposed to cadmium fumes. Presented at the Seminar on Occupational Exposure to Cadmium. London 1980.

38. Humperdinck K. Kadmium und Lungenkrebs. Med Klin 63 (1968) 948-951.

39. International Agency for Research on Cancer. Chemicals, industrial processes and industries associated with cancer in humans, volumes 1 to 29 . Lyon 1982. (IARC monographs on the evaluation of the carcinogenic risk of chemicals to humans, supplement 4).

40. Jacobson KB, Turner JE. The interaction of cadmium and certain other metal ions with proteins and nucleic acid. Toxicology $16(1980) 1-37$.

41. Johansson A, Camner P, Jarstrand C, Wiernik A. Rabbit alveolar macrophages after inhalation of soluble cadmium, cobalt, and copper: A comparison with the effect of soluble nickel. Environ Res 31 (1983) $340-354$.

42. Kazantzis G. Induction of sarcoma in the rat by cadmium sulphide pigments. Nature 198 (1963) $1213-1214$

43. Kazantzis G, Ades AE, Sallivan KA, Overell HM. Lung cancer in a lead zinc cadmium smelter. Presented at the International Conference on Heavy Metals in the Environment, Athens, Sept 10-13, 1985.

44. Kipling MD, Waterhouse JAH. Cadmium and prostatic carcinoma. Lancet 1 (1967) 730-731.

45. Kirk-Othmer. Encyclopedia of chemical technology. Volume 4. John Wiley and Sons, New York, Chichester, Brisbane, Toronto 1978, pp 397-441.

46. Kjellström T, Friberg L, Rahnster B. Mortality and cancer morbidity among cadmium-exposed workers. Environ Health Perspect 28 (1979) 199-204.

47. Lamm SH. Methodological problems underlying the cadmium controversy. Abstracts of the 1985 American Industrial Hygiene Conference, Las Vegas, May 19-24, 1985. American Industrial Hygiene Association, Cincinnati, OH 1985, pp 98-99.

48. Lee HY, Oberdörster G. Kinetics of intratracheally instilled $\mathrm{CdCl}_{2}$ and Cd-thionein. Toxicologist 5 (1985) 178.

49. Lemen RA, Lee JS, Wagoner JK, Blejer HP. Cancer mortality among cadmium production workers. Ann NY Acad Sci 271 (1976) 273-279.

50. Lewis GP, Jusko WJ, Coughlin LL. Cadmium accumulation in man: Influence of smoking, occupation, alcoholic habit and disease. J Chronic Dis 25 (1972) $717-726$.

51. Ley K, Arfors K-E. Changes in macromolecular permeability by intravascular generation of oxygen derived free radicals. Microvasc Res 24 (1982) 25-33.

52. Löser E. A two-year oral carcinogenicity study with cadmium on rats. Cancer Lett 9 (1980) 191-198.

53. Lundborg M, Ling B, Camner P. Ability of rabbit alveolar macrophages to dissolve metals. Exp Lung Res 7 (1984) $11-22$.

54. Malave I, deRuffino DT. Altered immune response during cadmium administration in mice. Toxicol Appl Pharmacol 74 (1984) 46-56.

55. McCay PB, King MM, Lai EK, Poyer JL. The effect of antioxidants on free radical productions during in vivo metabolism of carbon tetrachloride. J Am College Toxicol 2 (1983) 195-206.

56. Menzel DB. From animal to man, the grand extrapolation of environmental toxicology. In: Lee SD, Mudd $\mathrm{JB}$, ed. Assessing toxic effects of environmental pollutants. Ann Arbor Science, Publishers Inc/The Butterworth Group, Ann Arbor, MI 1979, pp 1-14.

57. Menzel DB. Ozone: An overview of its toxicity in man and animals. In: Miller FJ, Menzel DB, ed. Fundamentals of extrapolation modeling of inhaled toxicants. Hemisphere Publishing Corporation, Washington, New York, London 1984, pp 3-24.

58. Miller EC. Some current perspectives on chemical carcinogenesis in humans and experimental animals: Presidential address. Cancer Res 38 (1978) 1479-1496.

59. Morrow PE. Toxicological data on $\mathrm{NO}_{x}$ : An overview. In: Miller FJ, Menzel DB, ed. Fundamentals of extrapolation modeling of inhaled toxicants. Hemisphere Publishing Corporation, Washington, New York, London 1984, pp 25-47.

60. Morrow PE, Yu CP. Models of aerosol behavior in airways. In: Moren F, Newhouse MT, Dolovich MB, ed. Aerosols in medicine: Principles, diagnosis and therapy. Elsevier Science Publishers, Amsterdam, New York, Oxford 1985, pp 149-191.

61. Muhle E, Otto F, Hochrainer D, Baumert H-P. Effect of cadmium aerosol inhalation on alveolar macrophages of the rat. Gesellschaft für Aerosolforschung 7 (1979) $144-148$.

62. Nandi M, Slone D, Jick H, Shapiro S, Lewis GP. Cadmium content of cigarettes. Lancet 2 (1969) 13291330.

63. National Institute of Occupational Safety and Health. Current intelligence bulletin 42: Cadmium. Cincinna$\mathrm{ti}$, OH 1984. (DHHS (NIOSH) publication no 84-116).

64. National Research Council, Inhalation toxicology: The effect of sulfur oxides on the lung. National Academy of Sciences, Washington, DC 1978, pp 130-179.

65. National Swedish Environment Protection Board. The Swedish ban on cadmium. Solna 1982.

66. Nordberg GF, Anderson O. Metal interactions in carcinogenesis: Enhancement, inhibition. Environ Health Perspect 40 (1981) 65-81.

67. Oberdörster G, Baumert HP, Hochrainer D, Stöber W. The clearance of cadmium aerosols after inhalation exposure. Am Ind Hyg Assoc J 40 (1979) 443-450.

68. Oberdsörster G, Guth DJ, Lee YH, Mavis RD. Lung toxicity of cadmium: Importance of its chemical form. In: Lekkas TD, ed. Proceedings of the international conference on heavy metals in the environment. Volume 1. CEP Consultants, Edinburgh 1985, pp $571-574$.

69. Oberdörster G, Hochrainer D. Lung clearance of $\mathrm{Fe}_{2} \mathrm{O}_{3}$ - and $\mathrm{CdCl}_{2}$-aerosols during chronic $\mathrm{CdO}$ inhalation. Gesellschaft für Aerosolforschung 8 (1980) 198-203.

70. Oberdörster G, Hochrainer D, Ma RH. Zinc oxide aerosols: Generation, lung clearance and effect on lung clearance. Gesellschaft fur Aerosolforschung 7 (1979) $132-137$.

71. Oberdörster G, Hochrainer D, Oldiges H. Prevention of $\mathrm{CdO}$ induced impaired lung clearance by simultaneous $\mathrm{ZnO}$ inhalation. Toxicologist 2 (1982) 60.

72. Oberdörster G, Kördel W. Metallothionein content in lung, liver, and kidney after chronic cadmium oxide and zinc oxide inhalation in rats. In: CEP Consultants. Proceedings of the international conference on heavy metals in the environment. Edinburgh 1981, pp 502-505.

73. Oldiges H, Glaser U. Low level inhalation experiments with four different cadmium compounds in rats. Pre- 
sented at the sixth UOEH International Symposium and the Third COMTOX on Bio- and Toxicokinetics of Metals, Kitakyushu City, July 27-31, 1986.

74. Palmer KC, Snider GL, Hayes JA. Cellular proliferation induced in the lung by cadmium aerosols. Am Rev Respir Dis 112 (1975) 173-179.

75. Pershagen G. The carcinogenicity of arsenic. Environ Health Perspect 40 (1981) 93-100.

76. Pershagen G, Wall S, Taube A, Linnman L. On the interaction between occupational arsenic exposure and smoking and its relationship to lung cancer. Scand J Work Environ Health 7 (1981) 302-309.

77. Piscator M. Exposure to cadmium. In: DiFerrante D, ed. Trace metals: Exposure and health effects. Pergamon Press, Oxford, New York, Toronto, Sydney, Paris, Frankfurt 1979, pp 35-41.

78. Piscator M. Role of cadmium in carcinogenesis with special reference to cancer of the prostate. Environ Health Perspect 40 (1981) 107-120.

79. Piscator M, Kjellström T, Lind B. Contamination of cigarettes and pipe tobacco by cadmium-oxide dust. Lancet 2 (1976) 587.

80. Poirier LA, Kasprzak KS, Hoover KL, Wenk ML. Effect of calcium and magnesium acetate on carcinogenicity of cadmium chloride in Wistar rats. Cancer Res 43 (1983) 4575-4581.

81. Post CT, Squibb KS, Fowler BA, Gardner DE, Illing J, Hook, GER. Production of low molecular weight cadmium binding protein in rabbits lungs following exposure to cadmium chloride. Biochem Pharmacol 31 (1982) 2969-2975.

82. Potts CL. Cadmium proteinuria - The health of battery workers exposed to cadmium oxide dust. Ann Occup Hyg 8 (1965) 55-61.

83. Raabe OG, Yeh H-C, Newton GJ, Phalen RF, Velasquez DJ. Deposition of inhaled monodisperse aerosols in small rodents. In: Walton WH, McGovern B, ed. Inhaled particles, IV. Pergamon Press, Oxford, New York, Toronto, Sydney, Paris, Frankfurt 1977, pp $3-21$.

84. Rall DP. Validity of extrapolation of results of animal studies to man. Ann NY Acad Sci 329 (1979) 85-91.

85. Repine JE, Fox RB, Berger EM, Vatter A, Shasby DM, Bowman CM, Harada RN. Potential mechanisms of lung injury from hydroxyl radical. Chest 80 (1981) $45 \mathrm{~S}-48 \mathrm{~S}$.

86. Richters A, Kuraitis $\mathrm{K}$. Inhalation of $\mathrm{NO}_{2}$ and blood borne cancer cell spread to the lung. Arch Environ Health 36 (1981) 36-39.

87. Roels H, Bernard A, Buchet JP, Goret A, Lauwerys R, Chettle DR, Harvey TC, Haddad IA. Critical concentration of cadmium in renal cortex and urine. Lancet 1 (1979) 221.

88. Saffiotti U, Cefus F, Kolb LH. A method for the experimental induction of bronchogenic carcinoma. Cancer Res 28 (1968) 104-124.

89. Sanders CL, Mahaffey JA. Carcinogenicity of single and multiple intratracheal instillation of cadmium oxide in rats. Environ Res 33 (1984) 227-233.

90. Shippee RL, Burgess DH, Ciavarra RP, DiCapua RA, Stake PA. Cadmium-induced suppression of the primary immune response and acute toxicity in mice: Differential interaction of zinc. Toxicol Appl Pharmacol 71 (1983) 303-306.

91. Shukla GS, Singhal RL. The present status of biological effects of toxic metals in the environment: Lead, cadmium, and manganese. Can J Physiol Pharmacol
62 (1984) 1015-1031.

92. Smith TJ, Anderson RJ, Reading JC. Chronic cadmium exposures associated with kidney function effects. Am J Ind Med 1 (1980) 319-337.

93. Snider GL, Hayes JA, Korthy AL, Lewis GP. Central lobular emphysema experimentally induced by cadmium chloride aerosol. Am Rev Respir Dis 108 (1973) $40-48$.

94. Snyder WS, Cook MJ, Nasset ES, Kerhausen LR, Howells GP, Tipton IH, ed. Report of the Task Group on Reference Man. Pergamon Press, Oxford, New York, Toronto, Sydney, Braunschweig 1975, p 172. (International Commission on Radiological Protection, no 23).

95. Sorahan T, Waterhouse JAH. Mortality study of nickel-cadmium battery workers by the method of regression models in life tables. Br J Ind Med 4 (1983) $293-300$.

96. Sorokin SP, Brain JD. Pathways of clearance in mouse lungs exposed to iron oxide aerosols. Anat $\operatorname{Rec} 181$ (1974) $581-626$.

97. Stutts MJ, Boucher RC, Gatzy JT. Effects of cadmium and zinc on canine tracheal bioelectric properties. Toxicol Appl Pharmacol 64 (1982) 147-154.

98. Susuki Y, Charg J, Ono T. Phagocytic activity of the alveolar epithelial cells in pulmonary asbestosis. Am J Pathol 69 (1972) 373-388.

99. Takenaka S, Oldiges H, König H, Hochrainer D, Oberdörster G. Carcinogenicity of cadmium chloride aerosols in Wistar rats. J Natl Cancer Inst 70 (1983) 367-373.

100. Task Group on Metal Interaction. Factors influencing metabolism and toxicity of metals: A consensus report. Environ Health Perspect 25 (1978) 3-41.

101. Thun MT, Schnorr TM, Smith AB, Halperin WE, Lemen RA. Mortality among a cohort of US cadmium production workers - An update. J Natl Cancer Inst 74 (1985) 325-333.

102. Verma MP, Sharman RP, Bourcier DR. Macromolecular interaction with cadmium and the effect of zinc, copper, lead, and mercury ions. Biol Trace Element Res 4 (1982) 35-43.

103. Von Nieding G. Possible mutagenic properties and carcinogenic action of the irritant gaseous pollutants $\mathrm{NO}_{2}, \mathrm{O}_{3}$, and $\mathrm{SO}_{2}$. Environ Health Perspect $22(1978)$ 91-92.

104. Waalkes MP, Poirier LA. In vitro cadmium-DNA interaction: Cooperativity of cadmium binding and competitive antagonism by calcium, magnesium and zinc. Toxicol Appl Pharmacol 75 (1984) 539-546.

105. Welch K, Higgins I, Oh M, Burchfiel C. Arsenic exposure, smoking, and respiratory cancer in copper smelter workers. Arch Environ Health 37 (1982) 325-335.

106. White LD, Varner MO, Hine $\mathrm{CH}$, Crookston $\mathrm{F}$, Watson RB. An epidemiological study of cadmium exposed workers. Abstracts of the 1985. American Industrial Hygiene Conference, Las Vegas, May 19-24, 1985. American Industrial Hygiene Association, Cinninnati, OH 1985, p 179.

107. Yost KJ. Some aspects of the environmental flow of cadmium in the United States. In: Mennear $\mathrm{JH}$, ed. Cadmium toxicity. Marcel Dekker Inc, New York, Basel 1979, pp 181-206.

Received for publication: 4 December 1985 